\title{
AN INNOVATIVE FORMULATION OF PARAFFIN AND SILICONE OILS FOR THE CONTROL OF THE RED POULTRY MITE (Dermanyssus gallinae) - EXAMINATION OF THE EFFICIENCY UNDER LABORATORY CONDITIONS
}

\author{
Aleksandar Pavlićević ${ }^{1 *}$, Radomir Ratajac ${ }^{2}$, Milica Dotlić ${ }^{1}$, \\ Igor Stojanov', Ivan Pavlović ${ }^{3}$ \\ ${ }^{1}$ AVES MIT” DOO, Subotica-Bajmok, Cluster “Dermanyssus gallinae”, Serbia \\ ${ }^{2}$ Scientific Veterinary Institute „Novi Sad“, Novi Sad, Serbia \\ ${ }^{3}$ Institute of Veterinary Medicine of Serbia, Belgrade, Serbia
}

\section{Abstract}

The past decades of clinical practice in poultry farming are characterized by inadequate control of one of the most important poultry ectoparasite, the red poultry mite (Dermanyssus gallinae). Therefore, the program for control of D. gallinae based exclusively on a physical mechanisms of action of acaricides has been developed in Serbia since 2012. By the beginning of 2017, a synergistic relationship between paraffin and silicone oils was observed by our team, and its efficiency in preventing the red poultry mite from respiring was examined. For laboratory examination the Petri dish and tin-box methods were used. Direct, full 1-minute exposure of adult mites to the recommended (15 and 20\%) or even much lower concentration of the formulation resulted in $100 \%$ mortality after 24 hours. Subsequent 1 -hour exposure (24 hours after application onto treated non-absorbent surface of adult mite) resulted in $100 \%$ mortality with the same concentrations. The long term effect depends on the surface quality. The concentrations of 15 and $20 \%$ provide $100 \%$ long-term effect after a 1-hour exposure period, and remains fully effective over the following 4-month period. In the following months (8 months), the formulation continues to work with a slightly lesser, however, still significant effect. The formulation is most effective on a plastic surface, where the full effect is achieved with significantly lower concentrations. The formulation has no effect on eggs; however, after the short development cycle is completed in the egg (2-6 days) and exit from

${ }^{1 *}$ Corresponding author email: zemljadrveca@gmail.com 
the shell, the larva is immediately exposed to the effects of the formulation and eliminated. High efficiency of the paraffin and silicone oils formulation, which has been established in laboratory conditions, justifies its use to the purpose of D. gallinae control in cages and equipment before flock settlement as well as in transport cages after cleaning and disinfection.

Key words: D. gallinae, paraffin and silicone oil, laboratory examination, efficiency

\title{
INOVATIVNA FORMULACIJA PARAFINSKOG I SILIKONSKIH ULjA ZA KONTROLU CRVENE KOKOŠIJE GRINjE (Dermanyssus gallinae) - LABORATORIJSKO ISPITIVANJE EFIKASNOSTI
}

\author{
Aleksandar Pavlićević ${ }^{1 *}$, Radomir Ratajac ${ }^{2}$, Milica Dotlić ${ }^{1}$, \\ Igor Stojanov', Ivan Pavlović ${ }^{3}$ \\ ${ }^{1}$ AVES MIT" DOO, Subotica-Bajmok, Cluster "Dermanyssus gallinae", Srbija \\ ${ }^{2}$ Naučni institut za veterinarstvo „Novi Sad“, Novi Sad, Srbija \\ ${ }^{3}$ Naučni institut za veterinarstvo Srbije, Beograd, Srbija
}

\section{Kratak sadržaj}

Protekle decenije kliničke prakse u živinarstvu karakterišu se pogrešnim pristupom i neadekvatnom kontrolom najznačajnijeg ektoparazita živine, crvene kokošije grinje (Dermanyssus gallinae). Iz tog razloga se od 2012. godine u Srbiji razvija programska kontrola D. gallinae, bazirana isključivo na fizičkom dejstvu. Ograničenosti postojećih preparata i metoda iziskivali su unapređenja. Početkom 2017. godine našim istraživanjima je utvrđen sinergizam parafinskog i silikonskog ulja i ispitivana je njenu efikasnost $\mathrm{u}$ sprečavanju respiracije crvene kokošije grinje. U laboratorijskom ispitivanju korišćena je metoda petrijeve šolje i limenih kutija. Direktnim, punim izlaganjem adulta u ekspoziciji od 1 minut, nakon 24 časa, utvrđen je $100 \%$ mortalitet, kod preporučenih (15 i 20\%), ali i znatno nižih koncetracija formulacije. Naknadnim izlaganjem (24 sata od nanošenja) na tretiranu ne upijajuću površinu adulta u trajanju ekspozicije od 1 sat utvrđen je 100\% mortalitet, kod preporučenih koncetracija 15 i 20\%. Produženo delovanje je u zavisnosti od kvaliteta podloge. Formulacija je najefikasnija na plastičnoj podlozi, gde se pun efekat ostvaruje i u značajno nižim koncetracijama. 
Pocinkovani lim zahteva povećanje koncetracije formulacije koje su optimalizovane za pripremu kaveza i opreme na $20 \%$. Ova koncetracija formulacije obezbeđuje 100\% efekat produženog delovanja u ekspoziciji od 1 sat, koje se nesmanjeno manifestuje u periodu od 4 meseca. U narednim mesecima ( 8 meseci), formulacija nastavlja da deluje nešto manjim, ali i danje značajnim dejstvom. Formulacija ne deluje na jaja. Međutim, posle završetka kratkog razvojnog ciklusa u jajetu (2-6 dana) i izlaska, larva biva odmah izložena dejstvu formulacije i eliminisana. Visoka efikasnost formulacije parafinskog i silikonskog ulja koja je utvrđena u laboratorijskim uslovima, opravdava njenu primenu na kavezima i opremi pred naseljavanje jata, i transportnim kavezima posle pranja i dezinfekcije, u cilju kontrole $D$. gallinae.

Ključne reči: Dermanyssus gallinae, parafinsko i silikonsko ulje, laboratorijsko ispitivanje, efikasnost

\section{INTRODUCTION}

The past decades of clinical practice in poultry farming are characterized by a wrong approach and inadequate control of the most important poultry ectoparasite, the red poultry mite (Dermanyssus gallinae). The evidence and consequence of such inadequate control is reflected in the current situation: high prevalence rates (Sparagano et al., 2009; Flochlay et al., 2017; Pavlićević et al., 2017; Pavlićević et al., 2017a), severe direct and indirect damages, negative effects on flock's health status and production results, and especially important toxicological risk in egg production such as the most recent fipronil incident (Pavlićević et al., 2017b).

Until now, synthetic chemical compounds manifesting neurotoxic effects (acaricides, in a broader sense - insecticides) were the dominant method of controlling D. gallinae (Wang et al., 2010; Sparagano, 2014; Flochlay et al., 2017). Moreover, their application has often been uncritical and almost regularly incompetent, which resulted in consequent spreading and progression of Derman$y$ ssosis disease. Moreover, there is a problem of emerging resistance of $D$. gallinae (Liebisch, 2003; Marangi et al., 2009; Pavlićević et al., 2016). Only the recent international fipronil incident has drawn the attention to a huge toxicological risk to which poultry farming was exposed, especially egg production.

Although there is a wide selection of various products and methods on the market, only selected $\mathrm{SiO}_{2}$ formulations offered an acceptable and safe al- 
ternative for the control of D. gallinae (Pavlićević et al, 2017c). However, $\mathrm{SiO}_{2}$ formulations have a far smaller range of practical uses than synthetic chemical unities with neurotoxic effects, and their drawbacks are evident. All aforementioned facts strongly suggest the necessity of improvement of D. gallinae control strategy.

Contrary to the generally accepted practices, programmed control of $D$. gallinae has been developing in Serbia since 2000 (P-441/01; Pavlićević et al., 2003; 2003a; 2007; 2007a; 2008; 2016; 2017a; 2017b; 2017c), and since 2012, the programme has exclusively been based on products with a physical effect (Pavlićević et al., 2017c). An innovative, professional, and full-scale program enabled the elimination of all risky substances, especially synthetic chemicals with a neurotoxic effect, from egg production. Beside the optimisation of $\mathrm{SiO}_{2}$ application we offered a completely new approach to physical control (Patent No P 547/17). By combining medicinal paraffin and silicone oil we determined a synergy which can provide essential product characteristics required for successful control of red poultry mite.

The aim of this research is to determine the efficiency of paraffin and silicone oils formulation (Pavlićević and Kovačević, 2017 (Patent No P 547/17)) on the red poultry mite (Dermanyssus gallinae) in laboratory conditions.

\section{MATERIALS AND METHODS}

The subject of testing was oil formulation consisting of paraffin and silicone oil (Patent No P 547/17) intended for preparation of cages before flock settlement in poultry industry. The formulation was applied in the form of aqueous emulsion at working concentration of $15-20 \%$. Laboratory tests encompassed the recommended concentrations (15-20\%), but also a range of lower concentrations such as $1,2,5,10$, and $12 \%$.

Biological test was performed on adults of the laboratory strain of D. gallinae (i.e., well-nourished female individuals) and their eggs. The laboratory strain of $D$ gallinae was grown in isolation chambers of the laboratory. Chambers were designed to enable favourable conditions for life and reproduction while still preventing their escape. Isolation chambers contained the cardboard traps, on which the mites were collected for the use in biological testing. The number of individuals per testing was 100, arranged in 5 dishes of 20 individuals each. Furthermore, the control group included 20 individuals per test. The mites were transferred using the needle, by grasping the ambulacra.

Laboratory examination implicated exposures of 1 minute, 1 hour, 24 hours and a continuous exposure (efficiency on D. gallinae eggs). In case of 
1-minute exposure, we performed the full exposure of individual mites, which were placed into a dish and the investigated product with a sufficient acaricidal effect was added onto them. Such exposition simulates the situation when a working emulsion is directly applied onto mites, resulting in a full exposure of the whole body. When the exposure was complete, the mites were transferred into a dish for observation (result analysis) and placed onto the filter paper (which covers the bottom of a clean Petri dish) in order to remove excess liquid and prevent asphyxiation. The mites were held in the same dish until the end of the test. The 1-hour exposure is considered the most important test as it defines the prolonged effect of the formulation. In case of 1 and 24-hour exposure, the sufficient amount of examined product at a desired concentration was introduced into the cylinder formed of Petri dishes, evenly spread by shaking, and the leftover was drained by turning and filtering. The dishes were dried at room temperature. The mites were introduced to the test dishes after applying the product and subsequent drying at room temperature for 24 hours.

When investigating the prolonged effect, repeated tests were performed on prepared test dishes at desired intervals. When the exposure was completed, the mites were transferred to a dish for observation (result analysis). After transferring, immediately after the exposure of mites to the product with an acaricidal effect, a knock-down effect was read. The mortality of D. gallinae in observation dishes was determined once a day during a 10-day period by visual examination utilizing a magnifier and a microscope. The mortality was assessed according the position of extremities and the body, motility, and morphological changes. The retention factor indicates to what extent the formulation inhibits the adults to escape the treated surface. The mortality was estimated 24 hours after exposure of mites to treated surface.

In this study, the sides of a plastic Petri dish or tin box were used as the testing surface. The materials used included plastic and galvanized sheet metal, which is commonly the material for the production of cages and equipment in poultry farming. Ambient conditions for testing were within the following ranges: temperature $17-26^{\circ} \mathrm{C}$ (average $21.62^{\circ} \mathrm{C}$ ), and humidity $39-69 \%$ (average $51.81 \%)$.

\section{Laboratory examination in plastic Petri dishes}

The test dishes are formed from plastic Petri dishes with dimension of 55 $\mathrm{mm}$ (outside measure) in a way that the identical rim sides of the Petri dish come together. In this manner, tall-form and short-form cylindrical dishes were created, in which the mites were tested for the acaricidal properties of 
the product. Cylinders made of high-rim sides were used for exposure, and those made of low-rim sides for observing the effects after the exposure. The preparation of the dishes made of high-rim side Petri dishes was done in a way to obtain a rough surface to enable even application of the examined solution, suspension, or powder. The preparation was performed using a wire attachment on the drill. After the mechanical preparation, the surface was wiped with concentrated alcohol for further degreasing and drying and used according to the exposure plan.

The effects of the formulation on egg viability were tested using plastic Petri dishes into which previously fed female mites were placed. After lying of eggs, the females were removed from the dish. The eggs were treated with the investigated formulation at high concentration $(20 \%)$ and subjected to continuous formulation exposure.

\section{Laboratory examination in tin boxes}

Two-part dishes made of galvanized sheet metal, which are put together to form a box were used. Dimensions of one part were $79 \times 100 \times 62 \mathrm{~mm}$, and the sides had an outside groove so that they would fit together. Tin boxes were used unprocessed and according the same method as the one used for the Petri dish. The examined formulation and mite individuals were placed inside the box.

Separate records were kept for each test - a report of laboratory examinations, where all important information was recorded.

\section{RESULTS}

The results of the experiment of direct exposure of $D$. gallinae to the oil formulation of paraffin and silicone oil (Patent No P 547/17) for the exposure time of 1 minute that simulates direct exposure during application are shown in Table 1.

Table 1. Exposure of D. gallinae to the oil formulation of paraffin and silicone oil (Patent No P 547/17) for 1 minute

\begin{tabular}{|l|c|c|c|c|c|c|}
\hline Working concentration of the emulsion (\%) & 1 & 2 & 5 & 10 & 15 & 20 \\
\hline Mortality of the experiment group (\%) & 100 & 100 & 98 & 100 & 100 & 100 \\
\hline Mortality of the control group (\%) & 0 & 5 & 5 & 0 & 0 & 0 \\
\hline Efficiency (\%) & 100 & 95 & 93 & 100 & 100 & 100 \\
\hline
\end{tabular}


The result of the experiment of direct exposure of D. gallinae to $1 \%$ emulsion of the oil formulation of paraffin and silicone oil (Patent No P 547/17) for the exposure time of 1 hour that simulate the occasion when D. gallinae, which are hidden during application, come into the contact with the formulation during activity, is shown in Table 2.

Table 2. The result of further exposure of D. gallinae to $1 \%$ emulsion of the oil formulation of paraffin and silicone oil (Patent No P 547/17) for 1 hour in plastic Petri dishes

\begin{tabular}{|l|c|c|c|c|c|c|c|c|}
\hline Day (month) of the residual effect & 1 & 84 & 85 & $\begin{array}{c}91 \\
(3)\end{array}$ & 98 & 189 & $\begin{array}{c}214 \\
\text { (7) }\end{array}$ & $\begin{array}{c}244 \\
(8)\end{array}$ \\
\hline $\begin{array}{l}\text { Mortality of the experi- } \\
\text { ment group (\%) }\end{array}$ & 100 & 100 & 100 & 99 & 99 & 96 & 89 & 79 \\
\hline $\begin{array}{l}\text { Mortality of the con- } \\
\text { trol group (\%) }\end{array}$ & 0 & 1 & 0 & 0 & 1 & 0 & 0 & 0 \\
\hline Efficiency (\%) & 100 & 95 & 100 & 99 & 94 & 96 & 89 & 79 \\
\hline
\end{tabular}

Mite deceased due to the effect of the investigated formulation, (Scanning electron micrograph (SEM)) is shown in Figure 1.

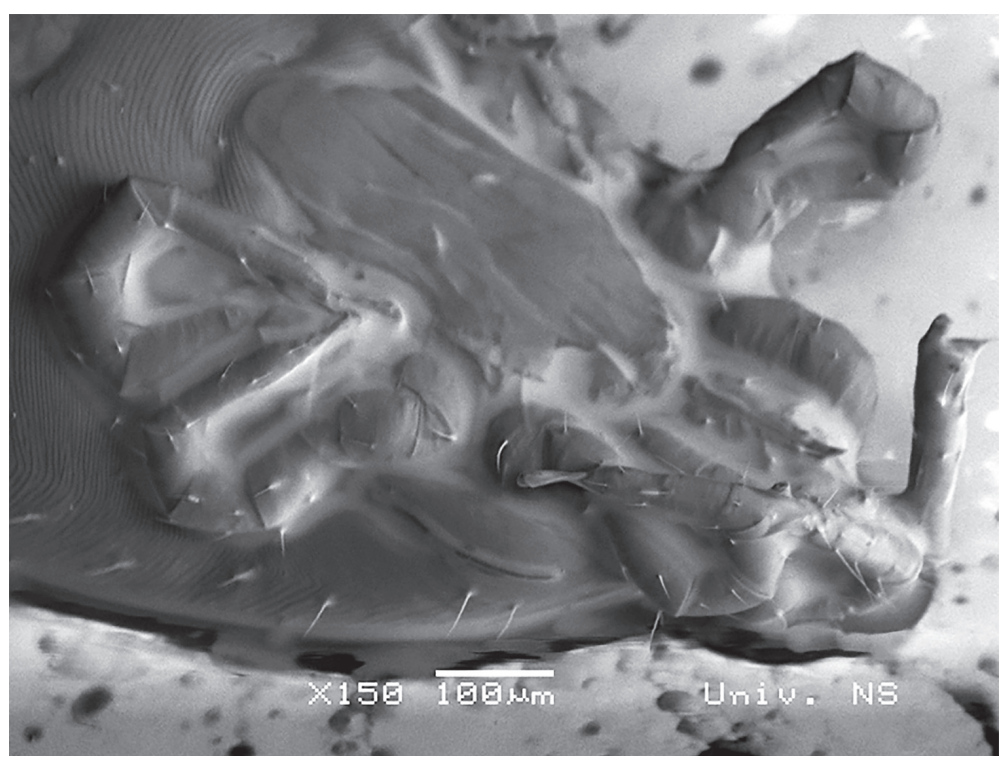

Figure 1. Mite died due to the effect of the investigated formulation, Scanning electron micrograph (SEM). 
The importance of the surface type for the residual effect of oil formulation of paraffin and silicone oil (Patent No P 547/17) is presented in Table 3.

Table 3. The result of further exposure of $D$. gallinae to $1 \%$ emulsion of the oil formulation of paraffin and silicone oil (Patent No P 547/17) for 1 hour, different surfaces

\begin{tabular}{|l|c|c|}
\hline \multicolumn{1}{|c|}{ Surface } & Plastic Petri dish & $\begin{array}{c}\text { Galvanized } \\
\text { sheet metal }\end{array}$ \\
\hline $\begin{array}{l}\text { Mortality of the experi- } \\
\text { ment group (\%) }\end{array}$ & 98 & 29 \\
\hline Mortality of the control group (\%) & 0 & 0 \\
\hline Efficiency (\%) & 98 & 29 \\
\hline
\end{tabular}

The result of the experiment of direct exposure of $D$. gallinae to different $\%$ of emulsion of the oil formulation of paraffin and silicone oil (Patent No $\mathrm{P}$ 547/17) for the exposure time (defined timeframes minute/hours) on galvanized sheet metal, are shown in Tables 4, 5 and 6 .

Table 4. Working concentration of $10 \%$ emulsion of oil formulation of paraffin and silicone oil (Patent No P 547/17) on galvanized sheet metal

\begin{tabular}{|l|c|c|c|c|c|c|c|c|c|}
\hline Day (month) of the residual effect & 1 & 1 & 12 & 30 & 35 & 42 & $(3)$ & $(4)$ & $(6)$ \\
\hline $\begin{array}{l}\text { Mortality of the } \\
\text { experiment group (\%) }\end{array}$ & 97 & 96 & 99 & 100 & 99 & 100 & 96 & 90 & 90 \\
\hline Mortality of the control group (\%) & 0 & 1 & 0 & 0 & 0 & 0 & 2 & 0 & 0 \\
\hline Efficiency (\%) & 97 & 91 & 99 & 100 & 99 & 100 & 85 & 90 & 90 \\
\hline
\end{tabular}

Table 5. Working concentration of $15 \%$ emulsion of oil formulation of paraffin and silicone oil (Patent No P 547/17) on galvanized sheet metal

\begin{tabular}{|l|c|c|c|c|c|c|c|c|c|c|}
\hline $\begin{array}{l}\text { Day (month) of the re- } \\
\text { sidual effect }\end{array}$ & 1 & 1 & 10 & 21 & 30 & 67 & $(3)$ & 115 & $(4)$ & $(5)$ \\
\hline $\begin{array}{l}\text { Mortality of the experi- } \\
\text { ment group (\%) }\end{array}$ & 97 & 100 & 99 & 98 & 99 & 97 & 94 & 100 & 87 & 88 \\
\hline $\begin{array}{l}\text { Mortality of the control } \\
\text { group (\%) }\end{array}$ & 0 & 5 & 0 & 0 & 10 & 0 & 0 & 0 & 0 & 0 \\
\hline \begin{tabular}{l} 
Efficiency (\%) \\
\hline
\end{tabular} & 97 & 95 & 99 & 98 & 89 & 97 & 94 & 100 & 87 & 88 \\
\hline
\end{tabular}


Table 6. Working concentration of $20 \%$ emulsion of oil formulation of paraffin and silicone oil (Patent No P 547/17) on galvanized sheet metal

\begin{tabular}{|l|c|c|c|c|}
\hline \multicolumn{1}{|c|}{ Day (month) of the residual effect } & 1 & 67 & $(3)$ & $(4)$ \\
\hline Mortality of the experiment group (\%) & 100 & 100 & 100 & 100 \\
\hline Mortality of the control group (\%) & 0 & 0 & 0 & 0 \\
\hline Efficiency (\%)) & 100 & 100 & 100 & $100^{*}$ \\
\hline
\end{tabular}

* the full mortality is achieved 4 days after exposure, in comparison to previous tests in which it is 1 day

In Table 7, the experiment results for a 24-hour exposure of oil formulation of paraffin and silicone oil (Patent No P 547/17) on galvanized sheet metal are presented.

Table 7. The experiment results for a 24-hour exposure on galvanized sheet metal

\begin{tabular}{|l|c|c|c|c|}
\hline \multicolumn{1}{|c|}{ Concentration (\%) } & 10 & 12 & 15 & 20 \\
\hline Mortality of the experiment group (\%) & 100 & 100 & 100 & 100 \\
\hline Mortality of the control group (\%) & 0 & 0 & 0 & 0 \\
\hline Efficiency (\%) & 100 & 100 & 100 & 100 \\
\hline
\end{tabular}

The results of testing different concentrations of the oil formulation of paraffin and silicone oil (Patent No P 547/17) on plastic surface are shown in Tables 8 and 9, and the efficacy of the formulation on the eggs is shown in Table 10.

Table 8. Testing different concentrations of the working emulsion: 1, 5, 10, and 15\% on a plastic surface

\begin{tabular}{|l|c|c|c|c|c|}
\hline $\begin{array}{c}\text { Time of observation } \\
\text { (hours) }\end{array}$ & Water & $1 \%$ & $5 \%$ & $10 \%$ & $15 \%$ \\
\hline 1 & 24 & 79 & 87 & 100 & 100 \\
\hline 24 & 3 & 78 & 98 & 100 & 100 \\
\hline Temperature (C) & 22 & $25-27$ & $25-27$ & $25-27$ & $25-27$ \\
\hline Moisture (\%) & $51-56$ & $37-61$ & $37-61$ & $37-61$ & $37-61$ \\
\hline
\end{tabular}


Table 9. Testing concentrations of 15 and $20 \%$ emulsion on a tin surface, over a period of 30 days, with analysis on a weekly basis.

\begin{tabular}{|c|c|c|c|c|c|c|c|c|c|c|c|c|c|c|c|}
\hline Day & \multicolumn{3}{|c|}{1} & \multicolumn{3}{|c|}{7} & \multicolumn{3}{|c|}{14} & \multicolumn{3}{|c|}{21} & \multicolumn{3}{|c|}{30} \\
\hline $\begin{array}{l}\text { Concen. of } \\
\text { the work- } \\
\text { ing emul- } \\
\text { sion }(\%)\end{array}$ & $\%$ & $\mathrm{~T}^{*}$ & $\operatorname{Hum}^{* *}$ & $\%$ & $\mathrm{~T}$ & Hum. & $\%$ & $\mathrm{~T}$ & Hum. & $\%$ & $\mathrm{~T}$ & Hum & $\%$ & $\mathrm{~T}$ & Hum. \\
\hline 15 & 100 & 22 & $51-56$ & 95 & 20 & $50-47$ & 92 & 20 & $46-47$ & 94 & $19-20$ & 49 & 93 & 19 & $43-46$ \\
\hline 20 & 100 & 22 & $51-56$ & 98 & 20 & $47-50$ & 92 & 20 & $46-47$ & 97 & $19-20$ & 49 & 97 & 19 & $43-46$ \\
\hline
\end{tabular}

${ }^{\star}$ Temperature showed in ${ }^{\circ} \mathrm{C}$

** Humidity showed in \%

Table 10. Results of the laboratory experiment, signifying the viability of eggs exposed to the formulation emulsion

\begin{tabular}{|c|c|c|c|c|c|c|c|}
\hline \multirow{2}{*}{$\begin{array}{c}\text { Test } \\
\text { day }\end{array}$} & \multirow{2}{*}{$\begin{array}{c}\text { No. of } \\
\text { eggs }\end{array}$} & \multicolumn{2}{|c|}{ Larvae } & \multicolumn{2}{c|}{ Protonymphs } & \multicolumn{2}{c|}{ Ambient Conditions } \\
\cline { 3 - 8 } & Live & Dead & Live & Dead & $\begin{array}{c}\text { Tem- } \\
\text { perature }\end{array}$ & Moisture \\
\hline 1 & 29 & - & - & - & - & 18 & 42 \\
\hline 2 & 29 & - & - & - & - & 18 & 48 \\
\hline 3 & 21 & 8 & - & - & - & 17 & 42 \\
\hline 4 & 13 & 7 & 9 & - & - & 17 & 40 \\
\hline 5 & 7 & 3 & 19 & - & - & 17 & 42 \\
\hline 6 & 3 & 1 & 25 & - & - & 17 & 44 \\
\hline 7 & 3 & 0 & 26 & - & - & 17 & 42 \\
\hline 8 & 3 & 0 & 26 & - & - & 17 & 43 \\
\hline
\end{tabular}

tThe image of the egg and larvae (light microscope (200x)) used in the research are shown in Figures 2 . and 3.

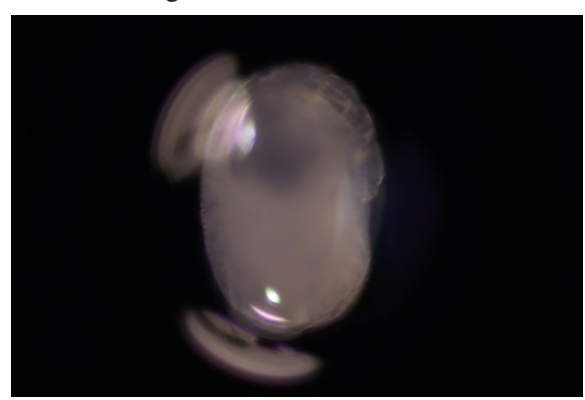

Figure 2. Egg, light microscope (200x)

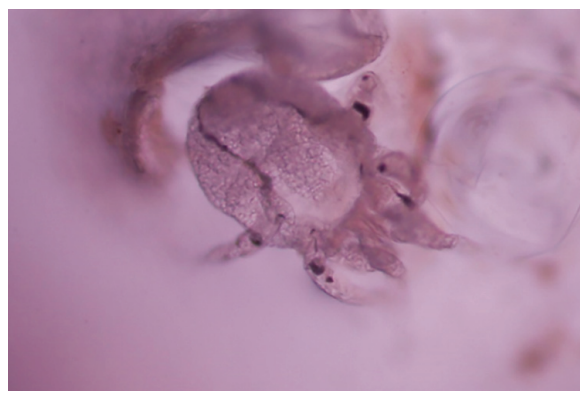

Figure 3. Larvae, light microscope (200x). 


\section{DISCUSSION}

According to our knowledge, there is no standardized method for laboratory and clinical examination of the efficiency of different acaricides on $D$. gallinae. The testing of biological efficiency of the formulation is highly challenging with regard to reproducibility and particularly to application in practice. We have been using the Petri dish method since 2000, and the quality of laboratory results has been checked in practice.

The biological test, Petri dish method, is one of the fundamental elements in the program for control of red poultry mite (Dermanyssus gallinae). The Petri dish method provides conditions for rational pharmacotherapy through selection of products with acaricidal properties, describing the pharmaco-toxicological profile, and monitoring the resistance, i.e., sensitivity - Patent No 441/01 (Pavličević, 2001).

In the presented study, the recommended concentrations for cage preparation before settlement were tested along with some lower concentrations in order to obtain more comprehensive idea of the formulation and its action.

The working concentration of formulation is used rather than a precise dose. The reason for this is to create the simulation of practical conditions. Testing in laboratory conditions commonly implicates testing of acaricides at highly precise doses (defined concentration and amounts per unit of surface), but the same precision cannot be repeated in practice, and thus, exact results cannot be expected. In practice, the dosage oscillates depending on the ambient conditions. Thus, the level of acceptance is crucial. Despite all of the above, laboratory studies generally should be an important guideline for further clinical trials. One-minute exposure provides information on the efficiency on directly exposed individuals during the very application of the formulation. This is the easiest "task" for the product intended for the control of D. gallinae. The laboratory test revealed $100 \%$ efficiency of product concentration of $10-20 \%$. However, a very high efficiency is evident even at $20 \mathrm{x}$ lower concentration.

One-hour exposure provides information about mites which escaped the direct application of the formulation, yet come in contact with it after leaving their shelter. This exposure is the most important one for efficiency assessment in laboratory conditions. It is evident that the absorptivity of the surface onto which the product is applied affects the effectiveness of formulation. On quickly absorbing surfaces, there is no residual effect. Preliminary application of the formulation on a concrete surface (regular concrete) resulted in quick drying of the surface, which did not justify the testing of a prolonged effect, thus, such tests have not been performed. 
On non-absorbable surfaces (galvanized metal and plastic), a layer that has a prolonged effect is created. The formulation is most efficient on a plastic surface (i.e., the less absorbable surface), where the full effect is achieved with lower concentrations. Galvanized metal requires an increased formulation concentration, which were optimized to $20 \%$ for the preparation of cages and equipment. This concentration provides $100 \%$ prolonged effect with an exposition of 1 hour which remains stable and consistent over a period of 4 months. During the following months (8 months), the formulation remains active to somewhat lesser, but still significant effect. Slightly lesser efficiency is observed with lower concentrations of the emulsion. However, concentrations of 10 and $15 \%$ demonstrate satisfactory efficacy that is applicable for practical control.

A 24-hour exposure does not simulate a situation in practical conditions, thus, it was used only for determining the tendency and comparability with other examinations (Sybil et al., 2011; Van Sauers, 2009). The full (100\%) effects of the control are observed at the examined concentrations of $10-20 \%$ on a galvanized metal surface.

Aside from the efficiency on directly exposed mites and a prolonged working on non-absorbable surfaces, the formulation also manifest particularly pronounced retention factor, which inhibits the escape of mites from the treated surface. The retention factor depends on the concentration of the formulation. It is optimally expressed at concentrations of $15-20 \%$. It is most expressed during the day one; however, its effects remain during at least 1 month.

We haven't confirmed any significant effect on eggs continually exposed to the formulation. Also, even mites that are lethally exposed to the effects of formulation can lay eggs until the moment of death. In case of sub-lethally exposed mites, we haven't noticed any significant influence on reproduction. However, the formulation remains active and affects the eggs, different developmental stages of mite as well as the reproduction cycle. The environment covered with a layer of formulation with prolonged effect is a trap for newly hatched larvae, which are prevented from moving and thus killed. The insecticidal effect of petroleum-derived spray oils has been known for more than one century (Agnello, 2002). Mineral oil works in a physical way by stopping respiration. Aside from a number of excellent properties, a lack of a prolonged effect was determined (Buteler and Stadler, 2011). However, this property itself is crucial for an efficient control of D. gallinae. The paraffin and silicone oil formulation was designed with the purpose of securing a prolonged effect. The morphological position of stigmas with $D$. gallinae offers the possibility of being inhibited by slightly oiled surfaces. However, at the same, time there is a need to avoid excessive dirt on the cages and equipment. Otherwise, excessive 
build-up of dirt on treated surfaces would prevent the prolonged effect thus creating unhygienic environmental conditions.

Mauer et al. (2009) determined certain level of efficiency of diesel oil. Also, they referred to the research of Guimaraes and Tucci (1992) who reported $100 \%$ efficiency of mineral oil after 2-hour exposure of directly treated D. gallinae. The investigations did not include the prolonged effect. In addition, the importance of the prolonged effect was neglected by many authors who addressed the topic of the effectiveness of essential oils (Van Sauers, 2009; Locher et al., 2010). Some examples of the confirmed prolonged effect are as following: azadirachtin - 11 days on impregnated filter paper (Locher, 2009); fluralaner (administered in drinking water) - persists for 15 days in the blood of the poultry (Heckeroth et al., 2015; Prohaczik, et al., 2017); spinosad - 21 days on different metal surfaces (George et al., 2010). An exceptional prolonged effect of carbaryl (70 days) was lost due to a development of resistance (Pavlićević et al., 2016).

Differently designed formulations, methods of application, and a nonstandardized methodology of laboratory examination does not allow proper comparability on the basis of laboratory experiments with contemporary active matters, such as fluralaner (Thomas et al., 2017), spinosad (George et al., 2010), phoxim and others (Locher, 2009; Sybil et al., 2011). In that respect, the comparability of the efficiency and profitability is to be further addressed and confirmed by clinical research.

Contrary to synthetic chemical substances with a neurotoxic properties (acaricides, in broader sense - insecticides), the development of the resistance is not likely due to the physical acaricidal effect of the product. Certain fluctuations in the efficiency do exist, and can be attributed to ideal coverage of the surface with the examined formulation.

The paraffin and silicone oil formulation works in a physical way, and is designed to maximally express its properties required for the control of $D$. gallinae. Having in mind the actual control methods (Sparagano et al., 2014; Flochlay et al., 2017), prolonged long-term effect of silicone-paraffin oil layer is considered a new and innovative approach (Patent No P 547/17) to the control of the red poultry mite. An approval of high efficiency and the aforementioned characteristics recommend the formulation for preparation of cages and equipment in poultry farming, before the flock settlement, as well as for transport cages. With a thorough preparation (cleaning and washing) and a rest of the facility, and subsequent professional application of the product, we can expect high efficiency of the formulation. An adequate preparation of the facility is considered crucial in preventive veterinary medicine and the control of the red 
poultry mite. The success of the control will be additionally increased by placing a layer of product with a prolonged effect on absorbable surfaces. One of potential solutions is spreading diatomic earth onto the floor. We expect that proper use of the formulation will enable a yearly exploitation of a layer flock. The properties of the formulation identified in this research through laboratory examination strongly suggest the possibility of an increased efficiency of eradication within the control program of D. gallinae. Further clinical examinations are needed to confirm the results acquired in laboratory conditions.

\section{CONCLUSION}

The high efficiency of the formulation based on paraffin and silicone oil (Pavlićević A. and Kovačević P., 2017 (Patent No P 547/17)), which has been determined under laboratory conditions, justifies its application for the control of D. gallinae on cages and equipment at the farm before settling the flock, and transport cages after thorough washing and disinfection (before using it for flock transport). The formulation has a potential for a high level of suppression, and as a part of a well-designed program, also for the eradication of $D$. gallinae from production facilities, i.e., poultry farms.

The final evaluation of the formulation will be possible after analysing the effects of $D$. gallinae control after preparation of cages for flock settlement throughout a one-year period of flock exploitation, as well as after comparing the results with comparative controls.

\section{REFERENCES}

1. Agnello A.M.: Petroleum - Derived spray oils: chemistry, history, refining and formulation. In: Spray Oils Beyond 2000, University of Western Sydney Press, Australia, 2002, 2-18.

2. Buteler M., Stadler T.: A Review on the Mode of Action and Current Use of Petroleum Distilled Sprey Oils. In: Pesticides in Modern World - Pesticides Use and Management, In Tech, Rijeka, 2011.

3. Flochlay A.S., Thomas E., Sparagano O.: Poultry red mite (Dermanyssus gallinae) infestation: a broad impact parasitological disease that still remains a significant challenge for the egg-laying industry in Europe. Parasites \& Vectors, 10, 357, 2017.

4. George D.R., Shiel R.S., Appleby W.G.C., Know A., Guy J.H.: In vitro and in vivo acaricidal activity and residual toxicity of spinosad to the poultry red mite, Dermanyssus gallinae. Veterinary Parasitology, 173, 307-16, 2010. 
5. Guimaraes J.H., Tucci E.C.: Evaluation of mineral oil in the control of Dermanyssus gallinae (De Geer, 1778) (Acari, Dermanyssidae) in field and laboratory conditions. Revista Brasileira de Entomologia 36, 859-862, 1992.

6. Heckeroth A.R., Zoller H., Flochlay-Sigognault A., Huyghe B.: Use of isooxazoline derivatives for the treatment or prevention of arthropod infestations in poultry. Patent WO2015091900A1, 2015.

7. Liebisch A., Liebisch G.: Biologie, Schäden und Bekämpfung beim Befall durch die Rote Vogelmilbe (Dermanyssus gallinae). Lomhmann Information, 4, 1, 2003.

8. Locher N.: Untersuchungen zur Wirksamkeit eines Neem-Präparates (Mite-Stop ${ }^{\circ}$ ) auf die Entwicklungsstadien der Roten Vogelmilbe Dermanyssus gallinae. Inaugural-Dissertation zur Erlangung des Grades eines Doktors der Veterinärmedizin an der Freien Universität Berlin vorgelegt von Tierärztin aus Mühlacker, Berlin. Journal- Natural Resources, 3332, 2009.

9. Locher N., Khaled A., Al-Rasheid S., Abdel-Ghaffar F., Mehlhorn H.: In vitro and field studies on the contact and fumigant toxicity of a neem-product (Mite-Stop ${ }^{\odot}$ ) against the developmental stages of the poultry red mite Dermanyssus gallinae. Parasitology Research, 107, 417-423, 2010.

10. Marangi M., Cafiero M.A., Capelli G., Camarda A., Sparagano O.A.E., Giangaspero A.: Evaluation of the poultry red mite, Dermanyssus gallinae (Acari: Dermanyssidae) susceptibility to some acaricides in field populations from Italy. Experimental and Apply Acarology, 48, 11-18, 2009.

11. Maurer V., Perler E., Heckendorn F.: In vitro efficacies of oils, silicas and plant preparations against the poultry red mite Dermanyssus gallinae. Experimental and Apply Acarology, 48, 31-41, 2009.

12. Pavlićević A.: Method for the laboratory examination of the efficiency, residual activity and resistance against ectoantiparasitic and insecticides in petri dish of poultry red mites Dermanyssus gallinae. Patent No: P 441/01, applied 18. Jun 2001. Savezni zavod za intelektualnu svojinu Beograd, Jugoslavija. Patent applicant: VZ "Subotica”a.d., Subotica, 2001.

13. Pavlićević A.: The GENIUS Prize for the invention" Method petri dish", $6^{\text {th }}$ of April, 2002, Budapest, Hungary.

14. Pavlićević A., Pavlović I., Stajković N., Pižurica A.: Programska kontrola crvene kokošije grinje (Dermanyssus gallinae) uputstvo proizvođačima. Živinarstvo, XXXVIII, 3-4, 11-15, 2003.

15. Pavlićević A., Petrićević S., Pavlović I., Stajković N., Pižurica A.: Prilog forenzičkoj proceni dermanisoze (Dermanyssosis). Veterinarski glasnik, 57, 7-8, 517-523, 2003a.

16. Pavlićević A., Pavlović I., Stajković N.: Method for early detection of po- 
ultry red mite Dermanyssus gallinae (DeGeer, 1778). Biotechnology in Animal Husbandry, 23, 3-4, 119 - 127, 2007a.

17. Pavlićević A., Pavlović I., Dotlić M.: A contribution to information on starvation survival capacity of poultry red mite Dermanyssus gallinae. Lucrari Stiintifice Medicina Veterinara, 50, 9, 485-491, 2007b.

18. Pavlićević A., Pavlović I, Dotlić M., Nemet A.: House fly Musca domestica like transmitter of red poultry mite Dermanyssus gallinae? World Poultry Science Journal, 64, supplement 1, 72-73, 2008.

19. Pavlićević A., Pavlović I., Stajković N. Bratislav P.: Evidence for Resistance to Carbaryl in Poultry Red Mites from the Republic of Serbia and Montenegro. Animal Science and Biotechnologies, 49, 1, 222-225, 2016.

20. Pavlićević A., Kovačević P.: Smeša koja sadrži parafinsko ulje kao insekticidno i akaricidno jedinjenje. Patent application No: P 547/17, patent applicant "Pullos" d.o.o., Belgrade and "Silikoni” d.o.o., Barič. Elp- 2017/0342, 2017.

21. Pavlićević A., JongUng Yoon, Pavlović I., Milanović M., Petrović T.: Control program of Dermanyssus gallinae and control of infectious diseases - draft of integrated healthcare. Book of Abstracts, XIX Sympozijum of Epizootiologist and Epidemiologist, Vršac, 05-07. April 2017a, 171-172.

22. Pavlićević A., JongUng Yoon, Vasić A., Pavlović I.: Cómo evitar casos como la contaminación de huevos con fipronil? Albéitar (Esp) 212, 51-53, 2017b.

23. Pavlićević A., Yoon J., Pavlovic I.: Control of red poultry mite (Dermanyssus gallinae) by mechanical effect: the choice of current improvements of formulations, application and concept. In: Abstract book, $3^{\text {rd }}$ COST Conference, Improving current understanding and research for sustainable control of the poultry red mite Dermanyssus gallinae (COREMI), 20-21. September, Oeiras, Portugal, 2017c, 40.

24. Prochaczik A, Menge M, Huyghe B, Flochlay-Sigognault A, Le Traon G.: Safety of fluralaner oral solution, a novel systemic antiparasitic treatment for chickens, in laying hens after oral administration via drinking water. Parasite \& Vectors, 10, 363, 2017.

25. Van Sauers A.: The contribution of red poultry mites (Dermanyssus gallinae (Degeer 1778) (Acari: Dermanyssidae)) to the cross contamination of poultry with Campylobacter spp. and Salmonella spp. and the acaricidal effect of carvacrol, thymol, bay oil and neem oil on Dermanyssus gallinae. Research Project, Veterinary Medicine University Utrecht. Department of IRAS, Veterinary Public Health Division, 2009.

26. Sparagano O.A.E., Pavlićević A., Murano T., Camarda A., Sahibi H., Kilpinen O., Mul M., van Emous R., le Bouquin S., Hoel K., Cafiero M.A.: 
Prevalence and key figures for the poultry red mite Dermanyssus gallinae infections in poultry farm systems. Experimental and Apply Acarology, 48, 3-10, 2009.

27. Sparagano O.A.E., George D.R., Harrington, D.W.J., Giangaspero, A.: Signification and Control of the Poultry Red Mite, Dermanyssus gallinae. Annual Review of Entomology, 59, 447-466, 2014.

28. Sybil J., Karamon J., Cencek T.: In vitro effectiveness of selected acaricides against red poultry mites (Dermanyssus gallinae, De Geer, 1778) isolated from laying hen battery cage farms localised in different regions of Poland. Bulletin of the Veterinary Institute in Pulawy, 55, 411-416, 2011.

29. Thomas E., Zoller H., Liebisch C., Flochlay-Sigognault A.: Comparative in vitro susceptibility of Dermanyssus gallinae field isolates to fluralaner, phoxim, spinosad, deltamethrin and propoxur. In: Abstract book, $3^{\text {rd }}$ COST Conference, Improving current understanding and research for sustainable control of the poultry red mite Dermanyssus gallinae (COREMI), 20-21.September, Oeiras, Portugal, 2017, 24.

30. Wang F.F., Wang M., Xu F.R., Liang D.M., Pan B.L.: Survey of prevalence and control of ectoparasites in caged poultry in China. Veterinary Record, 167, 934-937, 2010.

Primljeno: 29.11.2017.

Odobreno: 29.12.2017. 